\title{
Second Times Millimole per Milliliter
}

National Cancer Institute

\section{Source}

National Cancer Institute. Second Times Millimole per Milliliter. NCI Thesaurus. Code C85808.

Seconds times millimoles per milliliter. 